\title{
Generalized Energy and Ecological Characteristics of the Process of Co-Firing Coal with Biomass in a Steam Boiler
}

\author{
Joachim Kozioł $^{1} \mathbb{D}$, Joanna Czubala ${ }^{2}$, Michał Kozioł ${ }^{3}(\mathbb{D})$ and Piotr Ziembicki ${ }^{1, *(D)}$ \\ 1 Faculty of Civil Engineering, Architecture and Environmental Engineering, University of Zielona Góra, \\ Prof. Z. Szafrana 15 St., 65-516 Zielona Góra, Poland; kojo643@interia.pl \\ 2 TAURON Polish Energy Inc., Ściegiennego 3 St., 40-114 Katowice, Poland; joanna.czubala@wp.pl \\ 3 Faculty of Energy and Environmental Engineering, Silesian University of Technology, \\ 44-100 Gliwice, Poland; michal.koziol@polsl.pl \\ * Correspondence: p.ziembicki@iis.uz.zgora.pl
}

Received: 18 April 2020; Accepted: 15 May 2020; Published: 21 May 2020

\begin{abstract}
One of the ways used to reduce the emission of carbon dioxide and other harmful substances is the implementation of biomass co-firing processes with coals. Such processes have been implemented for many years throughout many countries of the world, and have included using existing high-power coal boilers. Despite numerous experiments, there are still no analyses in the literature allowing for their generalization. The purpose of this paper is to determine the generalized energy and ecological characteristics of dust steam boilers co-firing hard coal with biomass. The energy characteristics determined in the paper are the dependence of the gross energy efficiency of boilers on such decision parameters as their efficiency and the share of biomass chemical energy in fuel. However, the ecological characteristics are the dependence of emission streams: $\mathrm{CO}, \mathrm{NO}_{x}, \mathrm{SO}_{2}$, and dust on the same decision parameters. From a mathematical point of view, the characteristics are approximation functions between the efficiency values obtained from the measurements and the emission streams of the analysed harmful substances and the corresponding values of the decision parameters. Second-degree polynomials are assumed in this paper as approximation functions. Therefore, determining the characteristics came down to determining the constant coefficients occurring in these polynomials, the so-called structural parameters. The fit of the determined characteristics was assessed based on the coefficients of random variation and the test of estimated significance of structural parameters. Boiler characteristics can be used when forecasting the impact of changes in operating conditions on the effects achieved in existing, modernized, and designed boilers. The generalization of the characteristics was obtained from the measurement results presented in 10 independent sources used to determine them.
\end{abstract}

Keywords: steam boilers; co-firing; biomass; characteristics; boiler efficiency; GHG emissions; decision parameters; result parameters; structural parameters

\section{Introduction}

The specificity of the Polish energy system is one of the highest in the world's share of sources using coal (both hard and brown) in electricity production. In 2018, this share amounted to $78.2 \%$ [1]. For comparison, $12.8 \%$ of electricity came from renewable energy sources, wherein $3.9 \%$ came from sources using biomass (biogas plants, biomass combustion plants, and biomass co-firing) [1]. At the same time, the share of energy consumption from renewable sources in the entire energy balance in 2018 was $11.3 \%$ [2]. In 2017, solid biofuels accounted for $67.9 \%$ of energy obtained from renewable sources in Poland, and liquid biofuels accounted for 10\% [3]. Due to the geographical location (relatively low 
sun exposure and only locally occurring areas with more frequent strong winds) and the country's surface (flat with a lack of larger numbers of sizable rivers), until recently, hopes for the development of renewable energy sources in Poland were mainly associated with sources using biomass. Currently, due to the development of technologies in the field of solar energy, and in connection with projects to build a number of wind installations in the Baltic Sea, the prospective importance of these sources has grown.

Primary energy obtained in Poland from biomass sources corresponds to approximately 7.5 Mtoe [3]. This is a small amount in relation to the national biomass energy potential. This potential results from developed agriculture, using approximately 188 thousand $\mathrm{km}^{2}$ of arable land (nearly $60 \%$ of the country), and forest areas of 95 thousand $\mathrm{km}^{2}$ (30\% of the country area) [4]. The technical potential of biomass in Poland is estimated at around $930 \mathrm{PJ} /$ year [5]. This corresponds to almost 22.2 Mtoe per year. This potential mainly consists of waste wood from forests (200-240 PJ/year), energy crops (130 PJ/year), undeveloped straw (over $110 \mathrm{PJ} /$ year), post-use wood (over $40 \mathrm{PJ} /$ year), wastes from the wood industry (about $30 \mathrm{PJ} /$ year), and biomass from agricultural sources (about $15 \mathrm{PJ} /$ year) [5]. Thus, around $1 / 3$ of the domestic biomass energy potential is currently used.

Biomass co-firing with coal in large power boilers developed dynamically in Poland over the years 2005 to 2012. In the peak period, the co-firing process was responsible for about half of the electricity generated from renewable sources in Poland. Economic considerations, based on the introduced legal regulations, spoke in favour of the process. After 2012, due to the suspension of government support for this process, co-firing in large energy facilities began decreasing, and now only about $10 \%$ of electricity from 2012 is generated in this process. However, currently due to difficulties in meeting the national target of the share of renewable energy sources in gross final consumption in 2020, under the objectives of the European Union ( $20 \%$ EU, 15\% Poland), and a new, higher target for 2030 (32\% for the entire EU, no national target yet), the Polish government plans to allocate 10 billion PLN (over 2.2 billion EUR) to re-support this process [6].

It should be noted that although such a strong dependence on coal in the electricity sector is a Polish specificity, coal is still an important element of the power systems in a number of other countries, including Germany, China, Russia, India, Turkey, and South Africa. In addition, coal mining has increased in recent years, according to the International Energy Agency [7]. The organization forecasts that until 2024 its production will remain at a level similar to the current one. In addition, in non-OECD countries in 2017, electricity production from coal-fired installations accounted for $47 \%$ of the electricity produced [8].

Co-firing is a simple, cheap, and fast way to increase the production of electricity from renewable sources, as well as to reduce $\mathrm{CO}_{2}$ emissions from existing coal-fired installations. Appropriate installations already exist, and as a result of many years of process implementation, relevant experience in the process has been acquired in a number of countries. Experiments related to biomass co-firing in power plants and combined heat and power plants have been extensively discussed, e.g., in review works [9-12]. The advantages of the process include most often the reduction of greenhouse gas emissions $[9,10,13]$, and in the case of some installations and biomass, the reduction of $\mathrm{NO}_{x}$ emissions $[9,10,14]$, as well as the economic efficiency of the process (most often resulting from administrative and legal support activities) $[9,15,16]$.

Dust furnaces are one of the most frequently used constructions of large boilers for the implementation of co-firing of coals and biomass [9]. However, biomass co-firing in these units also has a number of disadvantages. These disadvantages concern both the installation itself and the entire biomass management. The latter include:

- Difficulties with the delivery of large amounts of biomass to individual co-firing installations (the need to transport biomass over long distances, including even its import);

- Environmental costs of biomass transport over considerable distances; 
- Lack of raw material for other biomass recipients, because the financial possibilities and obtained margin on sold energy from the co-firing process often allows operators of these installations to purchase biomass at much higher prices than the competition;

- Competition between energy crops and food crops.

Regarding the process disadvantages occurring in the installation itself, these should be mentioned:

- Reduction of boiler efficiency [17,18];

- Deposit formation, corrosion, and erosion of boiler components [10,12,19];

- Problems with milling and operation of coal mills, and in the fuel feeding system (increased fire risk and explosion) [20,21].

There are various ways to evaluate the effects of the co-firing process. Among them we can distinguish among others:

- Assessment of economic effects [15-17,22];

- Application of LCA (Life Cycle Assessment) methodology [23,24];

- Assessment of technical and ecological aspects $[10,12,18,19,21,22,25,26]$.

Data for conducted analyses are the result of process modeling, e.g., [14,22,27] or are obtained based on, e.g., measurements of emissions and installation efficiency during tests at industrial facilities $[19,21,25]$. As mentioned, many countries around the world are already very experienced in the implementation of co-firing coal and biomass in high power steam boilers. Despite this, however, there is a lack of literature attempting to generalize and mathematically describe it.

The main purpose of the study is to determine the generalized energy and ecological characteristics of co-firing coal with biomass in boilers with a capacity higher than $130 \mathrm{t} / \mathrm{h}$ of steam. The energy characteristics determine the impact of boiler efficiency and the biomass chemical energy stream (so-called decision parameters) on the gross energy efficiency of the boiler (so-called result parameter). On the other hand, ecological characteristics make it possible to assess the impact of these decision parameters on the corresponding resulting emissions of the following substances: carbon oxides $(\mathrm{CO})$, nitrogen oxides $\left(\mathrm{NO}_{x}\right)$, sulphur dioxide $\left(\mathrm{SO}_{2}\right)$, and dust.

Energy characteristics can be used to control the operation of steam boilers and are necessary when determining the optimal operating conditions for boilers being designed and modernized. The generalization of the characteristics made in this paper consist of using the authors' own measurements and information given in the literature to determine them.

\section{Materials and Methods}

\subsection{Method for Determining the Characteristics}

The characteristics are mathematical dependencies (functions) of the result parameters on the decision parameters. In the analysed case, the considered functions can be written as:

$$
\left.\begin{array}{l}
y_{1} \\
y_{2} \\
y_{3} \\
y_{4} \\
y_{5}
\end{array}\right\}=f\left(x_{1}, x_{2}\right)
$$

where: decision parameters: $x_{1}$-boiler efficiency, $\mathrm{t} / \mathrm{h}, x_{2}$-chemical biomass energy stream, MW; result parameters: $y_{1}$-boiler energy efficiency, $y_{2}$-emission of $\mathrm{CO}, \mathrm{kg} / \mathrm{h}, y_{3}$ - emission of $\mathrm{NO}_{x}, \mathrm{~kg} / \mathrm{h}$, $y_{4}$-emission of $\mathrm{SO}_{2}, \mathrm{~kg} / \mathrm{h}, y_{5}$ - emission of dust, $\mathrm{kg} / \mathrm{h}$. The analysed problem is shown in Figure 1. 


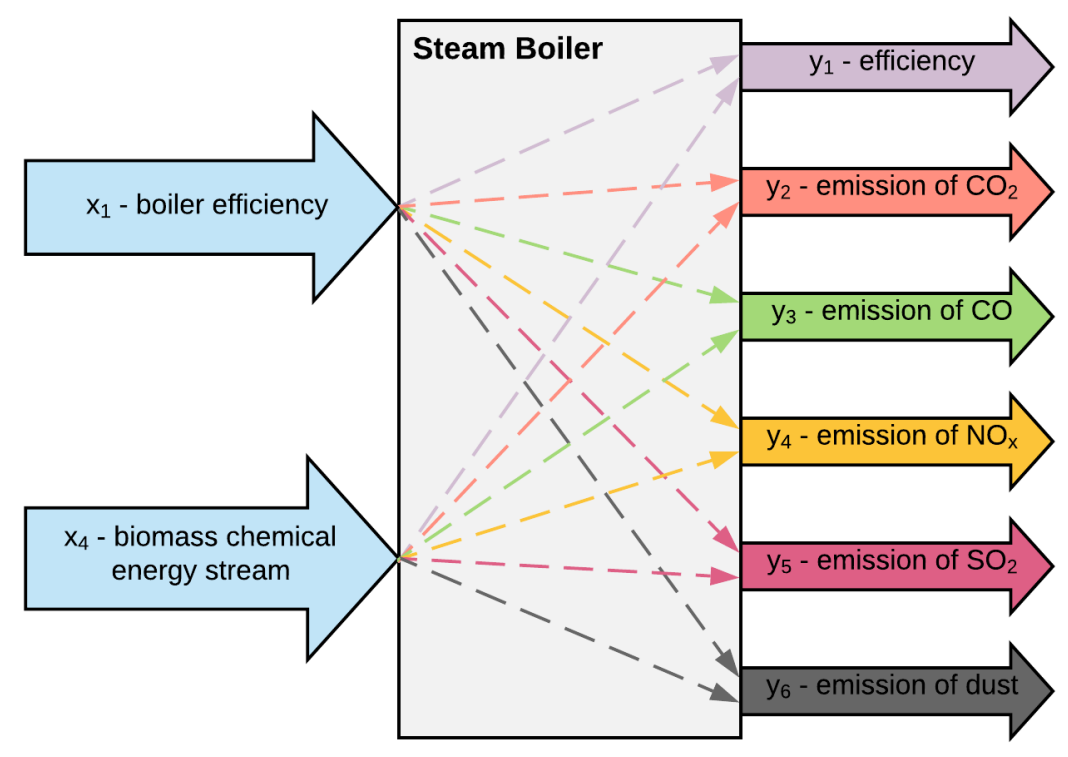

Figure 1. Characteristics of the test object.

The figure illustrates functional relationships between parameters resulting from decisive parameters. The characteristics are determined separately for individual analysed result parameters. These functions are approximation dependencies between the result parameter values obtained from the experiment and the combinations of decision parameter values characterizing them. Each of the combinations of decision values and the corresponding values of the resulting parameters is a measuring point.

It is recommended [28] to assume the form of object functions as second-degree polynomials. The following arguments support the use of a second order polynomial as a characteristic equation [28]:

- Its use is a compromise which, on the one hand, takes non-linearity of real test objects into account, and on the other hand, incorporates the tendency to reduce the number of measurements (an increase in the degree of polynomial significantly increases the number of tests necessary to carry out);

- It is characterized by high universality, as it allows adequate approximation of both simple linear and non-linear relationships;

- A polynomial is a particularly convenient form of a mathematical model in a case when only types of test factors and trends of their influence on the resulting factor are known.

In this case, it is proposed to take the following form of this function:

$$
y_{j}=b_{0}^{(j)}+b_{1}^{(j)} x_{1}+b_{2}^{(j)} x_{2}+b_{11}^{(j)} x_{1}^{2}+b_{22}^{(j)} x_{2}^{2}+b_{12}^{(j)} x_{1} x_{2}
$$

where: $b_{0}^{(j)}, b_{1}^{(j)}, b_{2}^{(j)}, b_{11}^{(j)}, b_{22}^{(j)}, b_{12}^{(j)}$-constant polynomial coefficients for the $j$-th result parameter, $j$-result parameter number $(j=1 \div 5)$.

According to the nomenclature used in statistical analyses in the remainder of the study, constant coefficients will be called structural parameters. Determining the characteristics comes down to determining the structural parameters in the individual characteristics. To determine the characteristics (function of the object), it is necessary to have a number of measurements that meet the condition:

$$
N \geq N_{b}
$$

where: $N$-number of measurements, $N_{b}$-number of structural parameters. 
In the case under consideration, the number of measurements should be greater (or at least equal) to six. At the same time, the greater the number of measurements above the number of structural parameters, the greater the reliability of the determined coefficients. A larger number of measurements make it possible to reduce the uncertainty of measurements on the results of the calculations. The values of constant coefficients are determined by statistical methods. Most often, modified methods of least squares of deviations are used for this purpose [29-31]. Examples of determining the characteristics are given in [32,33].

\subsection{Test Objects and Co-Firing Conditions}

The research presented in the study concerns dust steam boilers with an efficiency of 130 to $230 \mathrm{t} / \mathrm{h}$ of superheated steam at a pressure of 10 or $13.6 \mathrm{MPa}$ and a temperature of 450 or $540{ }^{\circ} \mathrm{C}$, respectively. The amount of biomass chemical energy in co-fired fuel ranged from 0 to $100 \mathrm{MW}$, which, depending on the boiler efficiency, ranged from $0 \%$ to even $100 \%$ of the total chemical energy of the fuel.

In determining the characteristics, the results of experiments carried out by the authors [32] or described in the literature $[19,27,34-40]$ were used. In order to determine the appropriate number of measurements and obtain the most representative results possible, the combinations of decision parameter values adopted for statistical analyses should be determined in accordance with the principles of scientific experiment planning [28-30,41]. Scientific planning of an experiment is possible when the determination of variants of systems of decision parameters (measuring points) precedes the measurements themselves. They are then carried out "on dictation" in strictly defined points of the research space (based on mathematical analyses). The authors attempted to adhere to these principles when determining the characteristics in the papers [32,33]. An analogous procedure was not possible when using the results of the experiments presented in the literature. In such cases, the values of decision parameters are determined by the authors "a priori" without scientific justification. At the same time, the use of information given in 10 independent sources to determine the characteristics allowed for generalization of the obtained results.

\section{Results}

\subsection{Obtained Characteristics}

Using the results of the experiments, structural parameters were estimated for each of the analysed object functions of the study. Table 1 shows the results obtained.

Table 1. Structural parameters of the characteristics.

\begin{tabular}{|c|c|c|c|c|c|c|}
\hline \multirow[b]{2}{*}{ No. } & \multirow[b]{2}{*}{$\begin{array}{l}\text { Coefficient } \\
\text { Designation }\end{array}$} & \multicolumn{5}{|c|}{ Coefficient Values for } \\
\hline & & $\begin{array}{c}\text { Boiler } \\
\text { Energy } \\
\text { Efficiency, } j=\mathbf{1}\end{array}$ & $\begin{array}{c}\text { Emission } \\
\text { of } \mathrm{CO} \\
\mathrm{kg} / \mathrm{h}, j=2\end{array}$ & $\begin{array}{c}\text { Emission } \\
\text { of } \mathrm{NO}_{x} \\
\mathrm{~kg} / \mathrm{h}, j=3\end{array}$ & $\begin{array}{c}\text { Emission } \\
\text { of } \mathrm{SO}_{2} \\
\mathrm{~kg} / \mathrm{h}, j=4\end{array}$ & $\begin{array}{c}\text { Emission } \\
\text { of Dust } \\
\mathrm{kg} / \mathrm{h}, j=5\end{array}$ \\
\hline 1 & $b_{0}$ & 0.8688 & -311.8 & 1563 & 5320 & -0.5138 \\
\hline 2 & $b_{1}$ & 0.0006 & 4.598 & -13.47 & -49.74 & 0.1185 \\
\hline 3 & $b_{2}$ & -0.0006 & -1.651 & 1.594 & 26.60 & 0.4437 \\
\hline 4 & $b_{11}$ & $-1.085 \times 10^{-6}$ & -0.01261 & 0.03571 & 0.1300 & -0.00011 \\
\hline 5 & $b_{22}$ & $4.236 \times 10^{-6}$ & 0.01471 & -0.02809 & -0.3471 & -0.00317 \\
\hline 6 & $b_{12}$ & $-8.760 \times 10^{-8}$ & 0.001065 & 0.01429 & 0.08572 & 0.00082 \\
\hline
\end{tabular}

\subsection{Verification of Characteristics}

The designated functions of the object were subjected to verification, which aimed to check whether the estimated functions describe the tested relationships well. The verification consisted of checking the following properties [42]: 
1. The degree of compliance of the constructed model with the measured data using [42,43]:

- Graphic comparison of the calculated values of the model with the measured data;

- Residual variance;

- Coefficient of random variation.

2. Quality assessment of structural parameters, requiring:

- Determination of standard errors in the estimation of structural parameters;

- Conducting the significance test of estimated structural parameters.

3.2.1. Verification of the Degree of Compliance of the Model with the Measurement Data

Graphic comparison of predicted values obtained from the characteristics with measured values is presented in Figures 2-6.

From the information given in Figure 2, there is a relatively high agreement between measured and predicted energy efficiency values. The value of an average standard deviation for individual characteristics is given in Table 2.

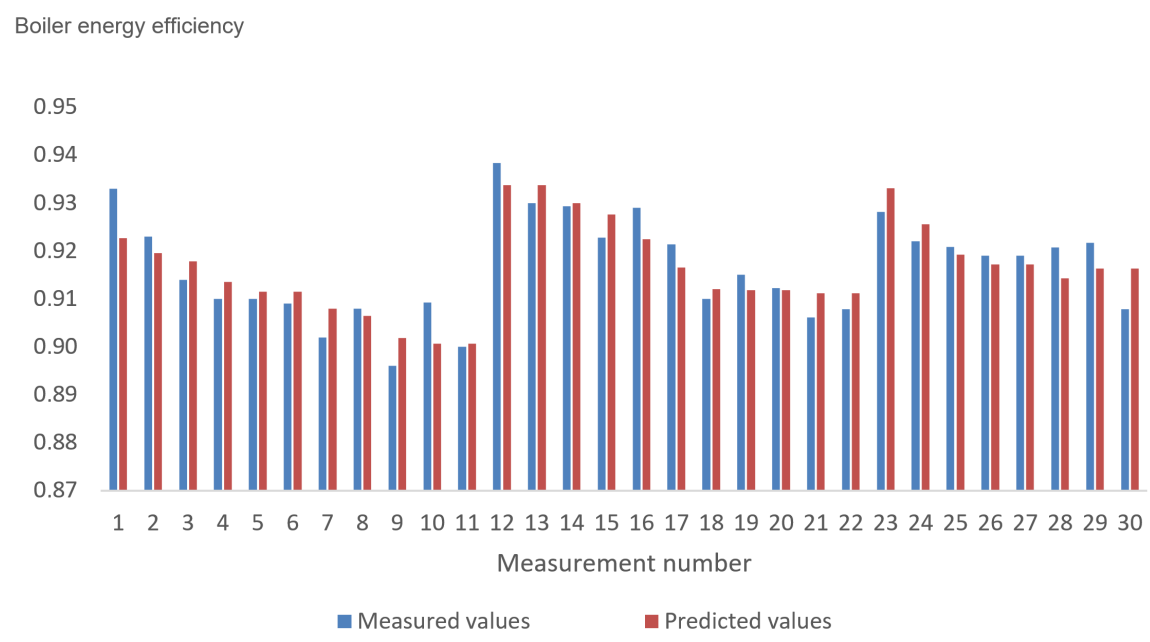

Figure 2. Comparison of the predicted values of the boiler energy efficiency model with measured values.

Table 2. Residual standard deviation.

\begin{tabular}{|c|c|c|c|c|c|}
\hline & \multicolumn{5}{|c|}{ Values Corresponding to the Designation of } \\
\hline & $\begin{array}{c}\text { Boiler } \\
\text { Energy } \\
\text { Efficiency, } j=1\end{array}$ & $\begin{array}{c}\text { Emission } \\
\text { of CO } \\
j=2 \\
\end{array}$ & $\begin{array}{c}\text { Emission } \\
\text { of } \mathrm{NO}_{x} \\
j=3 \\
\end{array}$ & $\begin{array}{c}\text { Emission } \\
\text { of } \mathrm{SO}_{2} \\
j=4 \\
\end{array}$ & $\begin{array}{c}\text { Emission } \\
\text { of Dust } \\
j=5 \\
\end{array}$ \\
\hline$s e^{2}$ & 0.0000 & 1155 & 9084 & 529,000 & 71.07 \\
\hline se & 0.01 & 33.99 & 95.31 & 727.3 & 8.43 \\
\hline
\end{tabular}

Figures 3 and 4 show that the differences between the measured and predicted values of $\mathrm{CO}$ and $\mathrm{NO}_{x}$ emission streams are relatively large. This applies in particular to measurements 14 and 15. It should be presumed that the measuring points relate to objects with various operating conditions, including the ratio of excess air for combustion and the design of the burners.

Figures 5 and 6 show large differences between the measured and predicted $\mathrm{SO}_{2}$ and dust emission streams. This applies, for example, to measurements 1, 12-15, 18, 20 and 24. It should be assumed that in these cases, decisive parameters should be supplemented with sulfur content and ash in coal and biomass. The authors were not in possession of such data. 


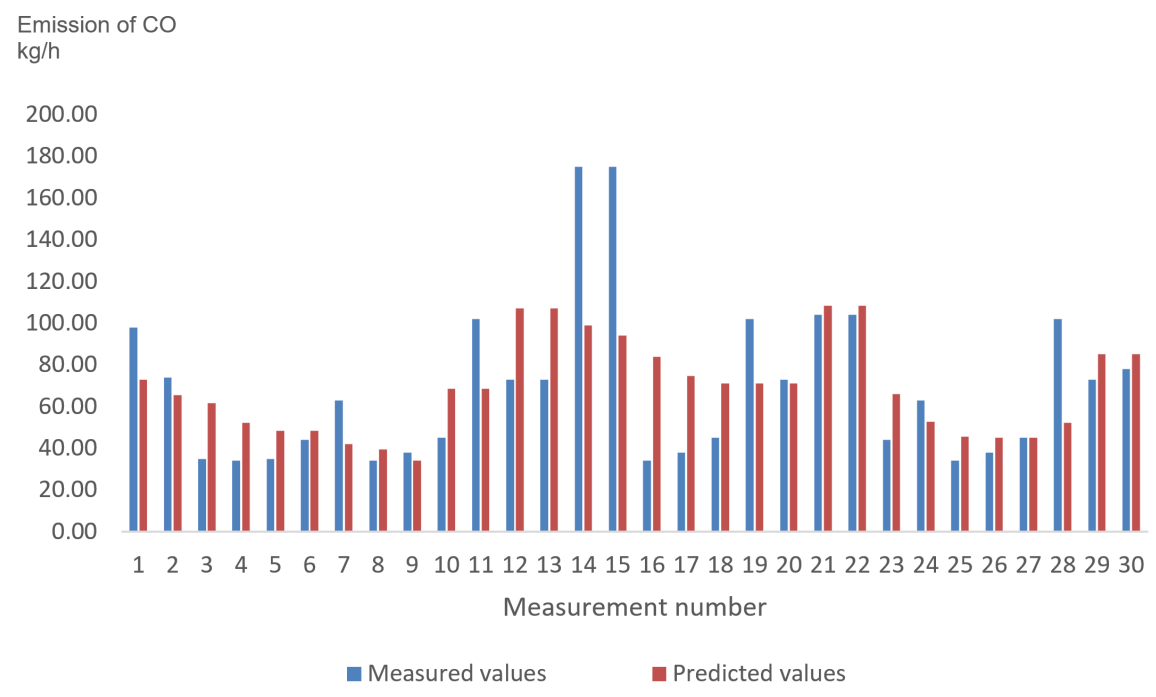

Figure 3. Comparison of the predicted values of the $\mathrm{CO}$ emission model with measured values.

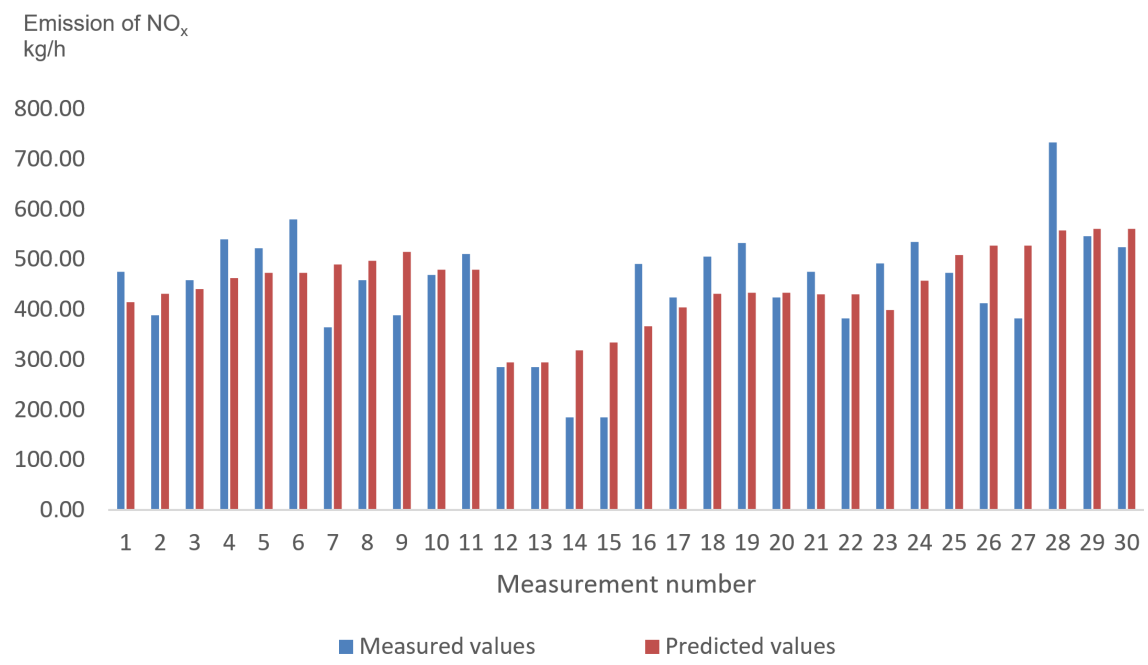

Figure 4. Comparison of the predicted values of the $\mathrm{NO}_{x}$ emission model with measured values.

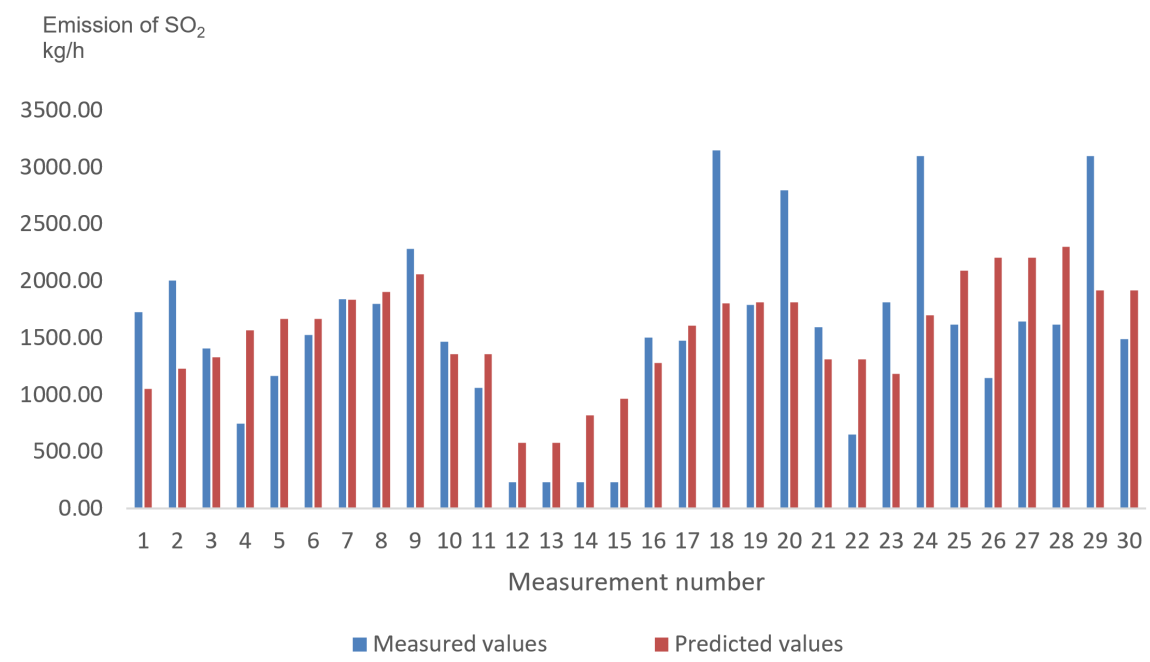

Figure 5. Comparison of the predicted values of the $\mathrm{SO}_{2}$ emission model with measured values. 


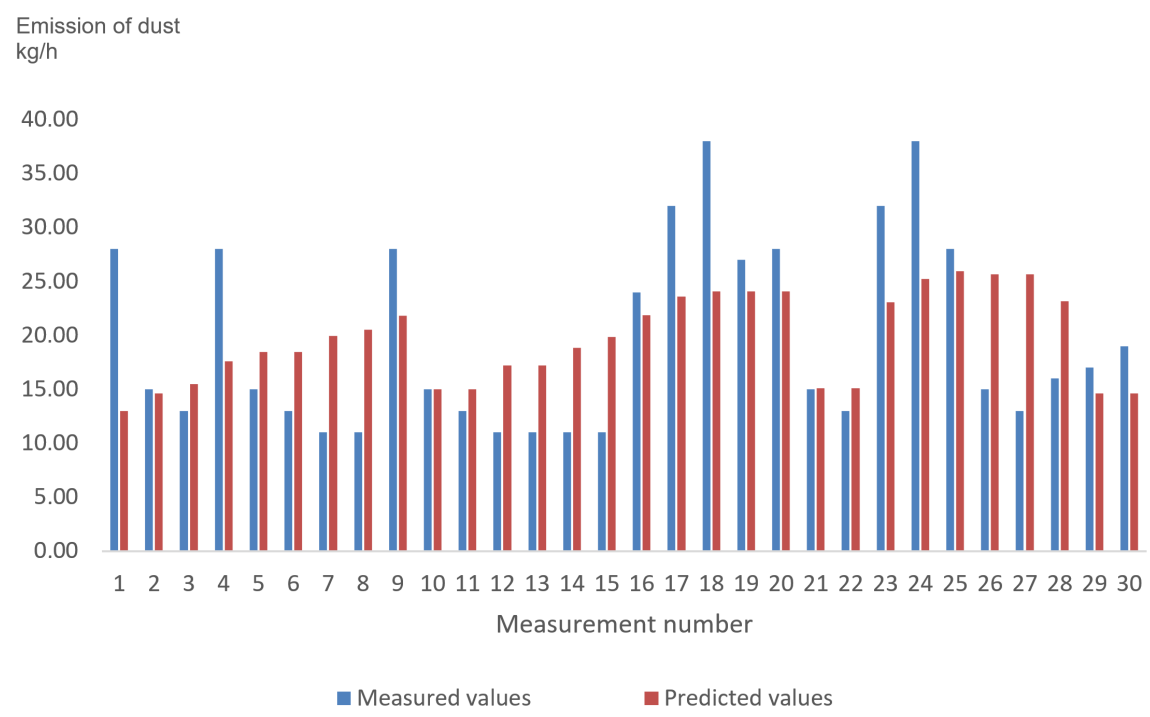

Figure 6. Comparison of the predicted values of the dust emission model with measured values.

Based on the graphical analysis of data obtained after estimating the structural parameters of the function, it can be seen that, in the case of boiler energy efficiency, they are well matched; in the case of ecological characteristics, the function matching is smaller.

Important information about the assessment of the compliance of the model with measured values is provided by the standard deviation of $s$ residues and the coefficients of random variation $v$. These values were determined in accordance with the recommendations given in the literature [42,43]. The obtained results are given in Tables 2 and 3.

The values given in Table 2 were used for calculations of data presented in Table 3.

Table 3. Arithmetic mean values and random coefficient of variation.

\begin{tabular}{cccccc}
\hline \multicolumn{6}{c}{ Values Corresponding to the Designation of } \\
\cline { 2 - 6 } & $\begin{array}{c}\text { Boiler } \\
\text { Energy }\end{array}$ & $\begin{array}{c}\text { Emission } \\
\text { of CO }\end{array}$ & $\begin{array}{c}\text { Emission } \\
\text { of } \mathbf{N O}_{x}\end{array}$ & $\begin{array}{c}\text { Emission } \\
\text { of } \mathrm{SO}_{\mathbf{2}}\end{array}$ & $\begin{array}{c}\text { Emission } \\
\text { of Dust }\end{array}$ \\
& Efficiency, $\boldsymbol{j}=\mathbf{1}$ & $\boldsymbol{j}=\mathbf{2}$ & $j=\mathbf{3}$ & $\boldsymbol{j}=\mathbf{4}$ & $\boldsymbol{j}=\mathbf{5}$ \\
\hline $\bar{y}$ & 0.92 & 69.17 & 447.9 & 1548 & 19.63 \\
$v_{e}$ & 0.01 & 0.49 & 0.21 & 0.47 & 0.43 \\
\hline
\end{tabular}

The coefficient of random variation $v$ is a relative measure of the diversity of the resulting parameters. It is the ratio of the standard deviation of the residuals and the arithmetic mean of the resulting parameter. It is assumed that its value should be less than 0.2 . This condition is met by efficiency characteristics and possibly $\mathrm{NO}_{x}$ emission characteristics

\subsubsection{The Importance of Structural Parameters}

According to information provided in the literature $[28,29,31,42,44]$, structural parameter $b$ is significant when the quotient of its value and the value of the average error of estimation of this parameter $s(b)$ (so-called Student test) is greater than the critical value $t_{c}$. The critical value $t_{c}$ depends on the confidence level $\alpha$ and the number of degrees of freedom $m=N-k-1$ (where: $k$-number of decision parameters). Its value can be read from commonly available tables. For $\alpha=0.05, m=$ $30-2-1=27$, critical value $t_{c}=2.052$.

Table 4 gives the values of the average error in estimating structural parameters $s(b)^{(j)}$. In turn, Table 5 gives the values of $t(b)^{(j)}$ for individual parameter. 
Table 4. Standard errors in estimating the structural parameters of the test object functions.

\begin{tabular}{|c|c|c|c|c|c|c|}
\hline \multirow[b]{2}{*}{ No. } & \multirow{2}{*}{$\begin{array}{c}\text { Indication } \\
\text { of Estimate } \\
\text { Error }\end{array}$} & \multicolumn{5}{|c|}{ Values of Errors in Determining } \\
\hline & & $\begin{array}{c}\text { Boiler } \\
\text { Energy } \\
\text { Efficiency, } j=1\end{array}$ & $\begin{array}{l}\text { Emission } \\
\text { of CO } \\
j=2\end{array}$ & $\begin{array}{c}\text { Emission } \\
\text { of } \mathrm{NO}_{x} \\
j=3\end{array}$ & $\begin{array}{c}\text { Emission } \\
\text { of } \mathrm{SO}_{2} \\
j=4\end{array}$ & $\begin{array}{c}\text { Emission } \\
\text { of Dust } \\
j=5\end{array}$ \\
\hline 1 & $s\left(b_{0}\right)$ & 0.0250 & 161.5 & 453.0 & 3457 & 40.06 \\
\hline 2 & $s\left(b_{1}\right)$ & 0.0003 & 1.880 & 5.270 & 40.22 & 0.4661 \\
\hline 3 & $s\left(b_{2}\right)$ & 0.0002 & 1.005 & 2.965 & 22.62 & 0.2622 \\
\hline 4 & $s\left(b_{11}\right)$ & $8.323 \times 10^{-7}$ & 0.0054 & 0.0151 & 0.1150 & 0.0013 \\
\hline 5 & $s\left(b_{22}\right)$ & $1.000 \times 10^{-6}$ & 0.0065 & 0.0181 & 0.1382 & 0.0016 \\
\hline 6 & $s\left(b_{12}\right)$ & $7.680 \times 10^{-7}$ & 0.0050 & 0.0139 & 0.1061 & 0.0012 \\
\hline
\end{tabular}

The values given in Table 4 were used for calculations of data presented in Table 5.

Table 5. Estimation of structural parameters relative to the error of estimation of the parameters.

\begin{tabular}{ccccccc}
\hline No. & $\begin{array}{c}\text { Indication } \\
\text { of Estimate } \\
\text { Error }\end{array}$ & $\begin{array}{c}\text { Boiler } \\
\text { Energy } \\
\text { Efficiency, } \boldsymbol{j}=\mathbf{1}\end{array}$ & $\begin{array}{c}\text { Emission } \\
\text { of CO } \\
\mathbf{j = 2}\end{array}$ & $\begin{array}{c}\text { Emission } \\
\text { of } \mathbf{N O}_{\boldsymbol{x}} \\
\mathbf{j = 3}\end{array}$ & $\begin{array}{c}\text { Emission } \\
\text { of } \mathbf{S O}_{\mathbf{2}} \\
\mathbf{j}=\mathbf{4}\end{array}$ & $\begin{array}{c}\text { Emission } \\
\text { of Dust } \\
\boldsymbol{j}=\mathbf{5}\end{array}$ \\
\hline 1 & $\left|b_{0}\right| / s\left(b_{0}\right)$ & 34.75 & 1.930 & 3.451 & 1.539 & 0.0128 \\
2 & $\left|b_{1}\right| / s\left(b_{1}\right)$ & 2.000 & 2.446 & 2.556 & 1.237 & 0.2541 \\
3 & $\left|b_{2}\right| / s\left(b_{2}\right)$ & 3.000 & 1.561 & 0.5376 & 1.176 & 1.692 \\
4 & $\left|b_{11}\right| / s\left(b_{11}\right)$ & 1.304 & 2.335 & 2.365 & 1.130 & 0.00846 \\
5 & $\left|b_{22}\right| / s\left(b_{22}\right)$ & 4.236 & 2.263 & 1.552 & 2.511 & 1.981 \\
6 & $\left|b_{12}\right| / s\left(b_{12}\right)$ & 0.1141 & 0.2130 & 1.028 & 0.8079 & 0.6833 \\
\hline
\end{tabular}

Comparing the values given in Table 5 with the critical value $t_{c}=2.052$, it should be stated that structural parameters play an important role: $b_{0}^{(1)}, b_{1}^{(1)}, b_{2}^{(1)}, b_{22}^{(1)}, b_{2}^{(2)}, b_{11}^{(2)}, b_{22}^{(2)}, b_{12}^{(2)}, b_{1}^{(3)}, b_{2}^{(3)}, b_{11}^{(3)}, b_{22}^{(4)}$. For dust emissions, none of the structural parameters meets the materiality criteria.

\subsection{Uncertainty of the Measured Quantity}

In this analysis, most of measurement results used came from literature sources cited in Section 2.2. Knowledge of the uncertainty (class) of measuring instruments and test methods used is required for adequate assessment of the uncertainty of measurement results. The instrument class is not provided in the used literature sources. Taking into account the efficiency of boilers, it should be assumed that their energy efficiency was determined by an indirect method requiring the determination of individual energy losses. This requires determining the uncertainty of complex quantities requiring more measurements. No further information was provided. At the same time, it should be noted that ignorance of the uncertainty of the measured quantities is not required to carry out the tests described in Sections 3.2.1 and 3.2.2.

\section{Discussion and Conclusions}

Generalizations of determined characteristics should be considered a valuable and innovative element of this study by using 10 variables and independent sources to determine them. The experimental results, taken into account from various sources, concerned boilers in which hard coal was burned with different elemental compositions. The same large variation occurred in the case of biomass. The major differences concerned especially the composition of the mineral substance and the sulphur content. It should be assumed that the design and operating conditions of the boilers also differed.

The main achievement of the work is to determine the studied characteristics and determine the ranges of their usefulness. 
The form of energy performance and ecological characteristics are set out in Table 2. The ranges of usability of these characteristics are varied. Energy performance can be used in the analysis of predictions in the field of technical and economic effects, especially useful when assessing the level of operation and modernisation of the existing dust steam boilers and the designing of new dust steam boilers with steam capacity from 130 to $230 \mathrm{t} / \mathrm{h}$.

For the $\mathrm{NO}_{x}$ emission stream characteristics, its usefulness should be assessed as less than that of energy performance. This is mainly due to the greater than 0.2 value of the random variation coefficient $v$ (see: Table 3). When assessing the usefulness of $\mathrm{CO}$ emission stream characteristics, it should be stated that the indicator $v$ significantly exceeds the standard value of 0.2 , but at the same time relatively favourable values are obtained when assessing structural parameter errors (see: Table 5). Therefore, it is proposed to use $\mathrm{NO}_{x}$ and $\mathrm{CO}$ characteristics for indicative analyses of boiler operation and design.

In turn, the determined characteristics of dust and $\mathrm{SO}_{2}$ emissions do not meet the statistical standards required for determining analogous relationships. This is evidenced by both graphically illustrated discrepancies between the predicted and measured values of these emissions (Figures 5 and 6), as well as the corresponding values of the random coefficient of variation $v$, significantly higher than 0.2. Additional confirmation of this fact lies in errors in the estimation of structural parameters related to these emissions (see Table 5).

Explanations of the reasons for unsatisfactory effects of determining ecological characteristics are given in the notes provided in Figures 4 and 6.

At the same time, the analyses showed that energy efficiency of boilers is adequately characterized by their efficiency and chemical energy of the burned biomass.

However, it should be noted that the operating conditions occurring in the analyzed boilers can significantly affect the values obtained on the basis of the $\mathrm{NO}_{x}$ and $\mathrm{CO}$ emission flux characteristics. The forms of these characteristics determined in the paper relate to average operating conditions occurring in boilers of this type during measurements.

Author Contributions: Conceptualization, J.K., J.C. and M.K.; methodology, J.K., J.C. and M.K.; software, J.C. and P.Z.; validation, J.C. and M.K.; data analysis, J.C. and M.K.; writing—original draft preparation, J.K., J.C. and M.K.; writing-review and editing, J.K. and P.Z.; funding acquisition, P.Z.; supervision, J.K. All authors have read and agreed to the published version of the manuscript.

Funding: This research received no external funding.

Conflicts of Interest: The authors declare no conflict of interest.

\section{References}

1. Macuk, R.; Maćkowiak-Pandera, J.; Gawlikowska-Fryk, A.; Rubczyński, A. Transformacja Energetyczna w Polsce_Edycja 2019; Technical Report; Forum Energii: Warszawa, Poland, 2019.

2. European Commission. Eurostat Database; Eurostat: Kirchberg, Luxembourg, 2020.

3. GUS. Statistics Poland. Energy from Renewable Sources in 2018; Technical Report; GUS: Warszawa, Poland, 2020.

4. GUS. Statistical Yearbook of the Republic of Poland 2019; Technical Report; GUS: Warszawa, Poland, 2018.

5. Bartoszewicz-Burczy, H. Biomass potential and its energy utilization in the Central European countries. Energetyka 2012, 12, 860-866.

6. Wiśniewski, G. Spalimy 10 Miliardów złotych. Wspótspalanie Wraca na Niespotykana̧ Skalę w Aukcjach 2020 na Energię z OZE; CIRE: Warszawa, Poland, 2020.

7. IEA. Coal Information: Overview, 2019 ed.; Technical Report; IEA: Paris, France 2019.

8. IEA. Coal 2019; Technical Report; IEA: Paris, France, 2019.

9. Roni, M.S.; Chowdhury, S.; Mamun, S.; Marufuzzaman, M.; Lein, W.; Johnson, S. Biomass Co-Firing Technology with Policies, Challenges, and Opportunities: A Global Review. Renew. Sustain. Energy Rev. 2017, 78, 1089-1101. [CrossRef]

10. Madanayake, B.N.; Gan, S.; Eastwick, C.; Ng, H.K. Biomass as an Energy Source in Coal Co-Firing and Its Feasibility Enhancement via Pre-Treatment Techniques. Fuel Process. Technol. 2017, 159, 287-305. [CrossRef] 
11. Cuellar, A.; Herzog, H. A Path Forward for Low Carbon Power from Biomass. Energies 2015, 8, 1701-1715. [CrossRef]

12. Kleinhans, U.; Wieland, C.; Frandsen, F.J.; Spliethoff, H. Ash Formation and Deposition in Coal and Biomass Fired Combustion Systems: Progress and Challenges in the Field of Ash Particle Sticking and Rebound Behavior. Prog. Energy Combust. Sci. 2018, 68, 65-168. [CrossRef]

13. Truong, A.H.; Patrizio, P.; Leduc, S.; Kraxner, F.; Ha-Duong, M. Reducing emissions of the fast growing Vietnamese coal sector: The chances offered by biomass co-firing. J. Clean. Prod. 2019, 215, 1301-1311. [CrossRef]

14. Milićević, A.; Belošević, S.; Crnomarković, N.; Tomanović, I.; Tucaković, D. Mathematical modelling and optimisation of lignite and wheat straw co-combustion in 350 MWe boiler furnace. Appl. Energy 2020, 260, 114206. [CrossRef]

15. Tan, P.; Ma, L.; Xia, J.; Fang, Q.; Zhang, C.; Chen, G. Co-firing sludge in a pulverized coal-fired utility boiler: Combustion characteristics and economic impacts. Energy 2017, 119, 392-399. [CrossRef]

16. Smith, J.S.; Safferman, S.I.; Saffron, C.M. Development and application of a decision support tool for biomass co-firing in existing coal-fired power plants. J. Clean. Prod. 2019, 236, 117375. [CrossRef]

17. Ko, S.; Lautala, P. Optimal Level of Woody Biomass Co-Firing with Coal Power Plant Considering Advanced Feedstock Logistics System. Agriculture 2018, 8, 74. [CrossRef]

18. Golec, T. Współspalanie biomasy w kotłach energetycznych. Energetyka 2004, 7, 11-24.

19. Sami, M.; Annamalai, K.; Wooldridge, M. Co-firing of coal and biomass fuel blends. Prog. Energy Combust. Sci. 2001, 27, 171-214. [CrossRef]

20. Gad, S.; Pawlak, A. Wpływ spalania biomasy na bezpieczeństwo procesu technologicznego w elektrowni konwencjonalnej. Logistyka 2014, 3, 1864-1870.

21. Steer, J.; Marsh, R.; Griffiths, A.; Malmgren, A.; Riley, G. Biomass co-firing trials on a down-fired utility boiler. Energy Convers. Manag. 2013, 66, 285-294. [CrossRef]

22. Xu, W.; Niu, Y.; Tan, H.; Wang, D.; Du, W.; Hui, S. A New Agro/Forestry Residues Co-Firing Model in a Large Pulverized Coal Furnace: Technical and Economic Assessments. Energies 2013, 6, 4377-4393. [CrossRef]

23. Kommalapati, R.; Hossan, I.; Botlaguduru, V.; Du, H.; Huque, Z. Life Cycle Environmental Impact of Biomass Co-Firing with Coal at a Power Plant in the Greater Houston Area. Sustainability 2018, 10, 2193. [CrossRef]

24. Yang, B.; Wei, Y.M.; Hou, Y.; Li, H.; Wang, P. Life cycle environmental impact assessment of fuel mix-based biomass co-firing plants with CO2 capture and storage. Appl. Energy 2019, 252, 113483. [CrossRef]

25. Zuwala, J.; Sciazko, M. Full-scale co-firing trial tests of sawdust and bio-waste in pulverized coal-fired 230t/h steam boiler. Biomass Bioenergy 2010, 34, 1165-1174. [CrossRef]

26. Zheng, S.; Yang, Y.; Li, X.; Liu, H.; Yan, W.; Sui, R.; Lu, Q. Temperature and emissivity measurements from combustion of pine wood, rice husk and fir wood using flame emission spectrum. Fuel Process. Technol. 2020, 204. [CrossRef]

27. Mehmood, S.; Reddy, B.V.; Rosen, M.A. Energy Analysis of a Biomass Co-firing Based Pulverized Coal Power Generation System. Sustainability 2012, 4, 462-490. [CrossRef]

28. Polański, Z. Planowanie Doświadczeń w Technice; PWN: Warszawa, Poland, 1984.

29. Montgomery, D. Design and Analysis of Experiments; John Wiley \& Sons Inc.: New York, NY, USA, 2001.

30. Myers, R.; Montgomery, D. Response Surface Methodology; Wiley \& Sons Inc.: New York, NY, USA, 1995.

31. StatSoft. Elektroniczny Podręcznik Statystyki PL; StatSoft: Warszawa, Poland, 2006.

32. Kozioł, J.; Czubala, J. An optimisation strategy using probabilistic and heuristic input data for fuel feeding boilers with regard to the trading effects of CO2 allowances. Energy 2013, 62, 82-87. [CrossRef]

33. Koziol, J.; Koziol, M. Determining operating characteristics of co-firing processes in grate furnaces. Fuel 2019, 258, 116164. [CrossRef]

34. Mann, M.; Spath, P. A life cycle assessment of biomass cofiring in a coal-fired power plant. Clean Prod. Processes 2001, 3, 81-91. [CrossRef]

35. Canalís, P.; Royo, J.; Sebastián, F. Influence of co-combustion in the efficiency of a pulverized coal boiler. In Proceedings of the 14th European Biomass Conference, Paris, France, 17-21 October 2005.

36. EPA. Biomass Combined Heat and Power Catalog of Technologies; Technical Report; EPA: Washington, DC, USA, 2007. 
37. Valero, A.; Canalís, P.; Palacio, J.; Pascual, J.; Royo, J.; Sebastián, F.; Tapia, R. Co-Firing of Low Rank Coal and Biomass: A Chance For Biomass Penetration in the Renewables; Technical Report; Center of Research for Power Plant Efficiency: Zaragoza, Spain, 2020.

38. Ściążko, M.; Zuwała, J.; Pronobis, M. Zalety i wady współspalania biomasy w kotłach energetycznych na tle doświadczeń eksploatacyjnych pierwszego roku współspalania biomasy na skalę przemysłową. Energetyka $i$ Ekologia 2006, 3, 207-220.

39. Nicholls, D.; Zerbe, J. Cofiring biomass and coal for fossil fuel reduction and other benefits-status of North American facilities in 2010. USDA For. Serv. Gen. Tech. Rep. PNW-GTR 2012, 867, 1-22. [CrossRef]

40. Zuwała, J. Wpływ współspalania biomasy z paliwami konwencjonalnymi na parametry eksploatacyjne pracy bloków energetycznych. Energetyka 2010, 2, 108-114.

41. Oehlert, G.W. A First Course in Design and Analysis of Experiments; Technical Report; University of Minnesota: Minneapolis, MN, USA, 2010.

42. Bartosiewicz, S. Estymacja Modeli Ekonometrycznych; PWE: Warszawa, Poland, 1989.

43. Sobczyk, M. Statystyka; PWN: Warszawa, Poland, 1996.

44. Welfe, W.; Welfe, A. Ekonometria Stosowana; PWE: Warszawa, Poland, 2004.

(C) 2020 by the authors. Licensee MDPI, Basel, Switzerland. This article is an open access article distributed under the terms and conditions of the Creative Commons Attribution (CC BY) license (http:/ / creativecommons.org/licenses/by/4.0/). 